\title{
GEOCHEMISTRY OF PERIDOTITES AND ECLOGITES FROM THE KELSEY LAKE KIMBERLITE, COLORADO-WYOMING, USA.
}

\author{
L. Pizzolato and D.J. Schulze \\ University of Toronto at Mississauga, Mississauga, ON. L5L 1C6, Canada
}

\section{INTRODUCTION}

The Kelsey Lake kimberlite is part of the State Line kimberlite district, which consists of 13 clusters and 12 isolated occurrences of kimberlite. Kelsey Lake kimberlite is located on the southern margin of the Wyoming Archean Province. This Devonian-aged kimberlite is located on the Colorado-Wyoming border and intrudes Precambrian granitic and metamorphic rocks of the Front Range. Kelsey Lake is unique in that it is the only State Line kimberlite that is an economic diamond deposit. The characteristics of the mantle beneath the Kelsey Lake kimberlite, in particular below Kelsey Lake, were investigated through the chemical composition of the peridotitic and eclogitic xenoliths.

\section{PERIDOTITES}

The highly altered peridotites at Kelsey Lake are predominantly garnet lherzolites, garnet-spinel lherzolites, and spinel lherzolites. Garnet harzburgites and wehrlites are less common. Major mineral chemistry of the garnet, clinopyroxene and spinel has similarities with those found at other State Line kimberlites (Eggler et. al., 1987; Pizzolato and Schulze, 1998). The peridotites are classified as infertile based on molar ratio $\mathrm{Cr} /(\mathrm{Cr}+\mathrm{Al})$ and $\mathrm{Mg} /(\mathrm{Mg}+\mathrm{Fe})$ of the $\mathrm{Cr}-$ pyropes and Cr-diopsides (Eggler et al., 1987).

Garnets are LREE depleted, typical of peridotite residue trace element patterns. Trace element data show no variation in garnet chemistry with depth. Trace element patterns for clinopyroxene indicate both a LREE enrichment trend and a LREE depletion trend.

Orthopyroxene and olivine are completely altered, and estimates of equilibration temperatures and pressures were determined using the single pyroxene geothermobarometer of Nimis and Taylor (2000). The P-T estimates indicate a perturbed geotherm at a depth of $150 \mathrm{~km}$ with equilibration on a $42 \mathrm{~mW} / \mathrm{m}^{2}$ subcratonic geotherm between $1005^{\circ}-1078^{\circ} \mathrm{C}$ and $43.0-45.4 \mathrm{kbar}$ and equilibration of a $45 \mathrm{~mW} / \mathrm{m}^{2}$ subcratonic geotherm between $1144^{\circ}-1232^{\circ} \mathrm{C}$ and 44.8-50.3 kbar (Fig. 1). The depth range of the peridotites is between $130-180 \mathrm{~km}$, a smaller range than peridotites described by Eggler et al. (1987) from other State Line kimberlites that extend to $200 \mathrm{~km}$. The higher temperature xenoliths are not deformed, whereas deformation is typical of high temperature xenoliths from Lesotho.

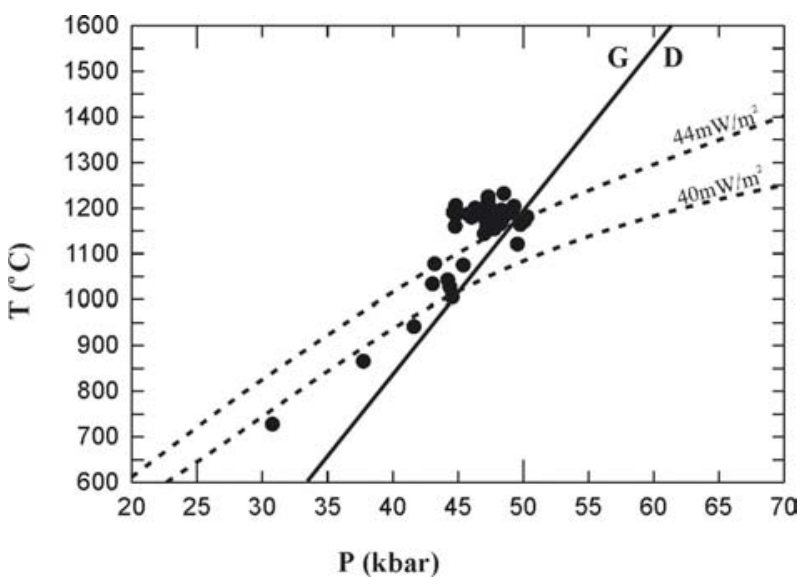

Figure 1: Pressures and temperatures for clinopyroxene in peridotites from Kelsey Lake using Nimis and Taylor's (2000) geothermobarometer. Solid line defines the graphite-diamond stability field, dashed lines are geotherms.

\section{ECLOGITES}

The eclogites at Kelsey Lake are $1.0-2.5 \mathrm{~cm}$ in size and subrounded to ellipsoidal in shape. Accessory minerals are kyanite, rutile, sphene, graphite and (primary) amphibole, and many contain secondary phlogopite, chlorite or amphibole. Some eclogites are foliated. The garnets are chemically homogenous. Most garnets correspond to group B of Coleman et al. (1965). A few eclogitic garnets fall into the $\mathrm{A}$ and $\mathrm{C}$ groups (Fig. 2). Garnet compositions are similar to those from Iron Mountain, Sloan and Schaffer (Ater et al., 1982). The clinopyroxenes are also similar to those found in eclogites from Schaffer and Iron Mountain. The clinopyroxenes were compared to those from South African eclogites where their origins have been suggested by Taylor and Neal (1989) to correspond to both $\mathrm{Na}_{2} \mathrm{O}$ and $\mathrm{MgO}$ values. The Kelsey Lake clinopyroxenes correspond to group A and B with one clinopyroxene extending to group C (Fig. 3). Taylor and Neal (1989) have suggested the African group A eclogites are cumulates with a mantle origin and those of groups $\mathrm{B}$ and $\mathrm{C}$ from a subducted oceanic crust.

The eclogites are divided into group I and II based on garnet $\mathrm{Na}_{2} \mathrm{O}$ and clinopyroxene $\mathrm{K}_{2} \mathrm{O}$ values (MacGregor and Carter, 1970; McCandless and Gurney, 1989) using the cutoff value of Gurney (1984) for $\mathrm{Na}_{2} \mathrm{O}$ in garnets at $0.07 \mathrm{wt} \%$. Both group I and II eclogites are represented at Kelsey Lake (Fig. 4). The Group II eclogites at Kelsey Lake 
have a lower $\mathrm{K}_{2} \mathrm{O}$ (cpx) value than the diamond eclogites at Sloan and those from South Africa (Schulze, 1992). Calculated equilibration temperatures, assuming a pressure of $50 \mathrm{kbar}$ and using Ellis and Green (1979) thermometer, yielded a wide temperature range for the eclogites from $600^{\circ}$ to $1480^{\circ} \mathrm{C}$. The Sloan diamond-bearing eclogites and the eclogite suite garnet-clinopyroxene pair found in Sloan diamonds both fall within this temperature range.

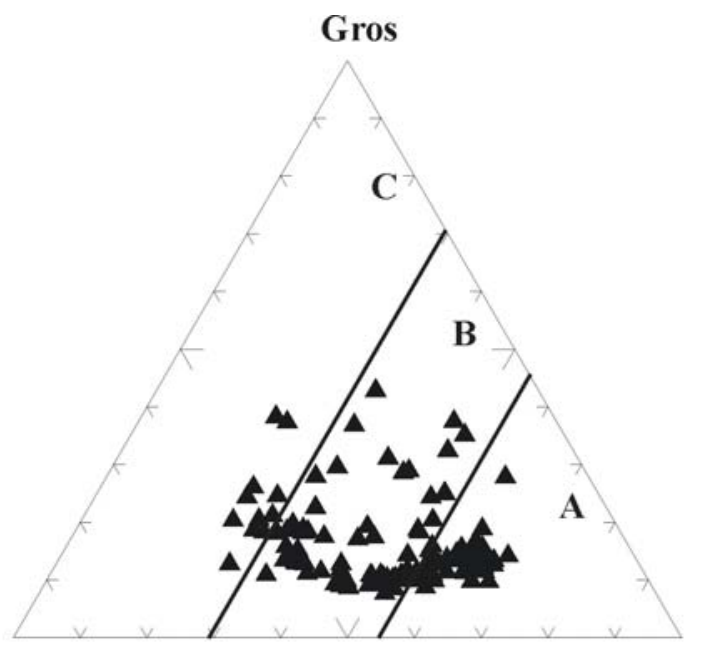

Alm+Spes

Pyr

Figure 2: Ternary diagram for garnets from Kelsey Lake eclogites. Boundaries from Coleman et al., (1965).

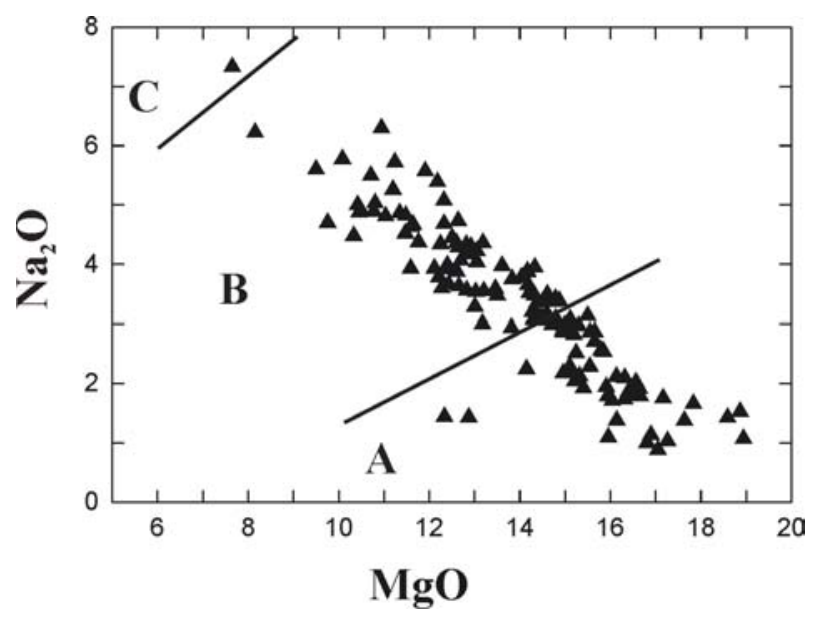

Figure 3: Clinopyroxenes from Kelsey Lake eclogites. Boundaries approximate those from Taylor and Neal (1989).

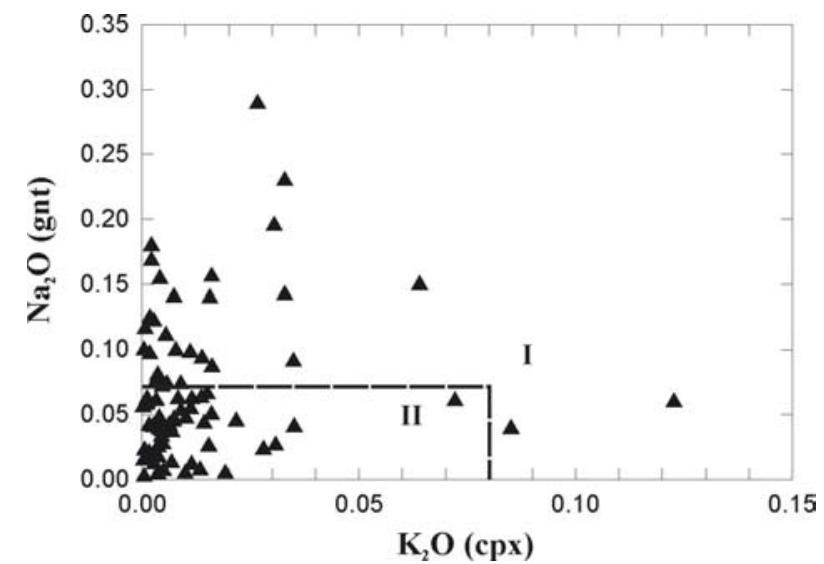

Figure 4: Correlation of $\mathrm{Na}_{2} \mathrm{O}$ in garnet ( $\mathrm{wt} \%$ ) and $\mathrm{K}_{2} \mathrm{O}$ in coexisting clinopyroxene (wt \%). Group I and II defined by a dashed line (from Gurney, 1984).

\section{DISCUSSION}

The mantle lithology is typical of a Proterozoic lithosphere (Eggler, 1987). The infertile peridotites are likely a residua from a Precambrian melting event involving the entire lithosphere, as suggested by Eggler et al., (1987) for other State Line occurrences. The peridotites may have been metasomatized at a shallower depth based on clinopyroxene trace element data and a Ti enrichment found in the peridotites. The presence of phlogopite and amphibole in veins in the eclogites also indicate they have been metasomatized. The perturbed geotherm observed from temperature data on the clinopyroxenes in the peridotites may suggest heating from the parent magma of the Cr-poor megacrysts, which are abundant at Kelsey Lake (Pizzolato and Schulze, 1998).

The origin of mantle eclogite xenoliths is a source of debate. It is widely held that many have their origin from recycled oceanic crust (Jacob et al., 1994), but it has also been suggested that eclogites may be of mantle origin as high pressure cumulates (Taylor and Neal, 1989). Based on mineralogy and mineral chemistry of the eclogites, neither subduction-related origin nor a mantle cumulate origin can be ruled out for the Kelsey Lake eclogites. The clinopyroxene in eclogites from Kelsey Lake are similar to South African eclogites in which some are interpreted to have a mantle cumulate origin and some originated from recycled oceanic crust. The wide temperature range of the eclogites also indicate that they were sampled by the kimberlites from within the diamond stability field to the uppermost mantle indicating both origins are possible. Oxygen isotope studies are in progress, which may provide data to discriminate between these hypotheses.

All evidence to date points to the Kelsey Lake diamonds being primarily peridotitic in origin. Diamondbearing Cr-pyrope harzburgitic garnets have been documented at Kelsey Lake (Pizzolato and Schulze, 1998) and the few diamond inclusion minerals studied so far 
belong to the peridotite-suite (Cr-pyropes and olivines). Although no diamonds belonging to the eclogite suite have been recognized, as Group I eclogites occur here, and eclogite equilibration temperatures extend to within the diamond stability field, a small proportion of the Kelsey Lake diamonds may be eclogitic.

\section{REFERENCES}

Ater, P.C., Eggler, D.H., and McCallum, M.E., 1984. Petrology and geochemistry of mantle eclogites xenoliths from Colorado-Wyoming kimberlites: Recycled oceanic crust? In: Kornprobst, J. (Ed.), Kimberlites II: The mantle and crust mantle relationships. Amsterdam, Elsevier, pp. 309318.

Coleman, R.G., Lee, D.E., Beatty, L.B., and Brannock, W.W., 1965. Eclogites and eclogites: Their differences and similarities. Geological Society of America Bulletin. 76, 483-508.

Ellis, D.J., and Green, D.H., 1979. An experimental study of the effect of $\mathrm{Ca}$ upon garnet-clinopyroxene $\mathrm{Fe}-\mathrm{Mg}$ exchange equilibria. Contrib. Mineral. Petrol. 71, 13-22.

Eggler, D.H., McCallum, M.E., and Kirkley, M.B., 1987. Kimberlite-transported nodules from Colorado-Wyoming; A record of enrichment of shallow portions of an infertile lithosphere: Geological Society of America Special Paper. $215,77-90$.

Gurney, J.J., 1984. A correlation between garnets and diamonds. In: Glover, J.E., Harris, P.G. (Eds.), Kimberlite occurrence and origin: A basis for conceptual models in exploration vol. 8 University of Western Australia, pp. 376-383.

Jacob, D., Jagoutz, E., Lowry, D., Mattey, D. and Kudrjavtseva, G., 1994. Diamondiferous eclogites from Siberia: remnants of Archean oceanic crust. Geochim. et Cosmochim. Acta. 58, 5191-5207.

MacGregor, I.D., and Carter, J.L., 1970. The chemistry of clinopyroxenes and garnets of eclogite and peridotite xenoliths from the Roberts Victor mine, South Africa. Physics Earth Planet. Interiors. 3, 391-397.

McCandless,T.E., and Gurney, J.J., 1989. Sodium in garnet and potassium in clinopyroxene: Criteria for classifying mantle eclogites. In: Ross, J., (Ed), Kimberlites and related rocks. Vol 2: Their mantle/crust setting, diamonds and diamond exploration. Carlton, Australia, Blackwell, pp. 827-832.

Nimis, P. and Taylor, W.R., 2000. Single clinopyroxene thermobarometry for garnet peridotites. Part 1. Calibration and testing of a Cr-in-Cpx barometer and an enstatite-inCpx thermometer. Contrib. Mineral. Petrol.139, 541-554.

Pizzolato, L. A., and Schulze, D.J., 1998. Preliminary investigations of megacrysts and peridotites xenoliths from the Kelsey Lake kimberlite, Colorado-Wyoming, USA. $7^{\text {th }}$ International Kimberlite Conference, extended abstracts, Cape Town, pp. 693-695.
Schulze, D.J., 1992. Diamond eclogite from Sloan ranch, Colorado, and its bearing on the diamond grade of the Sloan kimberlite. Economic Geology. 87, 2175-2179.

Taylor, L.A. and Neal, C.R., 1989. Eclogites with oceanic crustal and mantle signatures from the Bellsbank kimberlite, South Africa. Part I: Mineralogy, petrography and whole-rock chemistry. J. Geol. 97, 551-567.

Contact: L. Pizzolato, University of Toronto at Mississauga, Mississauga, ON, L5L 1C6, Canada, E-mail: loriann@sympatico.ca. 